\title{
Wireless Sensor Network Design Using Multihop Based on Arduino and NRF24L01+
}

\section{Rancang Bangun Wireless Sensor Network Menggunakan Multihop Berbasis Arduino dan NRF24L01+}

\author{
Riza Alfita $^{1}$, Miftachul Ulum ${ }^{2}$, Mochammad Faris Kurniawan ${ }^{3 *}$, Hanifudin Sukri ${ }^{4}$ \\ \{riza.alfita@trunojoyo.ac.id ${ }^{1}$, miftachul.ulum@trunojoyo.ac.id ${ }^{2}$, farx.110@gmail.com ${ }^{3}$, hanifudin.sukri@ trunojoyo.ac.id ${ }^{4}$ \}
}

Program Studi Teknik Elektro, Fakultas Teknik, Universitas Trunojoyo Madura, Bangkalan, Madura

\begin{abstract}
The development of communication networks is very useful in daily activities such as wireless data communication, monitoring and system security. In this case, a wireless sensor network technology is known, which is very suitable when applied to a system with a large number of nodes and spread over a large enough area at a low cost. This wireless sensor network is a wireless communication network that supports communication between sensor nodes in a considerable distance by placing several sensors in an area. Generally, this Wsn consists of a sensor node and a server node in the form of a personal computer. The data from the reading of the CO gas value will be sent directly from the sensor node to the node server. This device is built using the nRF24LO1 module and the CO gas sensor using the MQ-7 sensor. This wireless sensor network communication system is built using multihop. From the activities it can be concluded that the success of sending data is influenced by the distance and number of nodes working on a topology, with the amount of data sent which is influenced by long distances and the large number of nodes, not all data is successfully received because of the large number of data collisions from each node.
\end{abstract}

Keywords - Wireless Sensor Network; Sensor Node; Server; MQ-7; nRF24L01+

\begin{abstract}
Abstrak. Perkembangan Jaringan komunikasi sangat berguna dalam kehidupan. Dalam hal ini dikenal teknologi wireless sensor network yang cocok apabila diterapkan pada sebuah sistem dengannode yang banyak dan tersebar pada area yang luas dengan biaya yang murah. Wireless sensor network ini adalah jaringan komunikasi tanpa kabel yang mendukung komunikasi antar sensornode dalam jarak yang cukup jauh dengan penempatan beberapa jumlah sensor yang tersebar. Wsn ini secara umum terdiri dari sensor node dan server node. Setiap sensor node yg berjumlah 9 terdapat sensor gas $C O$, data gas $C O$ akan dikirim dari node sensorke node server secara langsung. Perangkat ini menggunakan modulnRF24L01+ dan sensor gas CO MQ-7. Dari kegiatan dapat disimpulkan bahwa keberhasilan pengiriman data dipengaruhi jarak dan jumlah node yang bekerja pada suatu topologi, dengan banyaknya data yg dikirim dengan jarak yang jauh dan jumlah nodeyang banyak maka tidak semua data berhasil diterima karena banyaknya tabrakan data dari masing-masing node.
\end{abstract}

Kata Kunci - wireless sensor network; sensor node; server node

\section{Pendahuluan}

Dalam elektronik jaringan dikenal teknologi wireless sensornetwork yang sangat cocok apabila diterapkan pada sebuah sistem dengan jumah node yang banyak dan tersebar pada areayang cukup luas dengan biaya yang murah. Wireless sensor network ini adalah jaringan komunikasi tanpa kabel yang mendukung komunikasi antar sensor node dalam jarak yang cukup jauh dengan penempatan jumlah sensor yang banyak dantersebar pada suatu daerah yang luas

Teknologi wireless sensor network ini digunakan untukmengakusisi data dan mendistribusikan data yang dipantau dandikendalikan secara terpusat. WSN sangat efektif diaplikasikandi wilayah geografis yang luas atau wilayah dengan kondisiyang berbahaya karena orang tidak dapat memantau kondisiwilayah tersebut setiap saat. Penelitian ini juga sekaligusmenguji pengiriman modul nRF24L01+ yang harganya sangatmurah kerika diterapkan pada jaringan wireless sensor network. Pada penelitian ini penulis membangun sistem monitoring gas CO menggunakan komunikasi wireless sensor network dengam menggunakan 9 node sensor

\section{METODE}

\section{A. Dasar teori}

Wireless sensor network

Wireless sensor network (WSN) merupakan jaringan wireless yang menggunakan sensor untuk memonitor fisik atau kondisi lingkungan sekitar. sekarang WSN sudah digunakan dalam bidang industri dan penggunaan untuk kemudahan masyarakat sipil, 
Wireless Sensor Network (WSN) dalam bahasa Indonesia disebut Jaringan Sensor Nirkabel (JSN). WSN merupakan suatu jaringan nirkabel yang terdiri dari kumpulan node sensor yang tersebar di beberapa area tertentu. Tiap node sensor memiliki kemampuan untuk mengumpulkan data dan informasi yang nantinya akan dikirim ke server/base station. WSN adalah suatu infrastruktur jaringan wireless yang menggunakan sensor untuk memantau kondisi fisik atau kondisi lingkungan yang dapat terhubung ke jaringan. Masing-masing node dalam jaringan sensor nirkabel biasanya dilengkapi dengan radio transceiver atau alat komunikasi wireless lainnya, mikrokontroler, dan sumber energi yang biasanya adalah baterai.

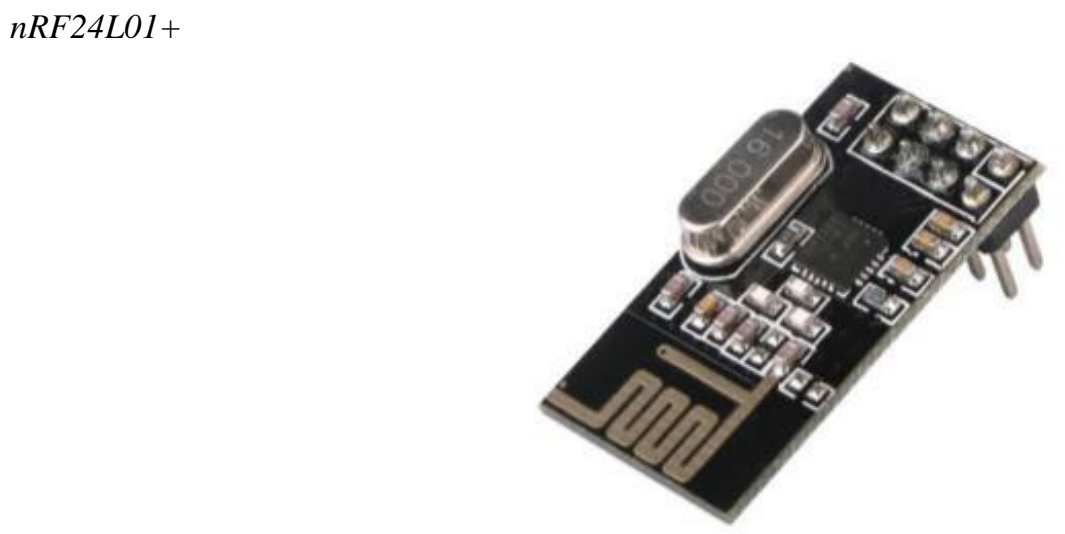

Gambar 1. Modul nRF24L01+

Transceiver nRF24L01+ adalah sebuah modul komunikasi jarak jauh yang memanfaatkan pita gelombang Radio Frekuensi 2,4 GHz ISM (Industrial Scientific and Medical). Modul ini menggunakan antarmuka SPI untuk berkomunikasi. nRF24L01 merupakan transceiver yang terdiri dari frequency synthesizer yang terintegrasi, power amplifier, osilator kristal, modulator, demodulator, dan enhanced shockburst protocol engine. nRF24L01+ merupakan sebuah modul komunikasi yang dapat dan menerima data secara half duplex. Frekuensi yang digunakan modul ini adalah $2.4 \mathrm{GHz}$. Untuk dapat mengirim dan menerima data, modul ini harus diberikan sebuah alamat (address) untuk dirinya dan tujuan. Transceiver ini sangat powerfull karena bisa menerima data dari banyak node yang alamat tujuannya sama.

\section{Arduino uno}

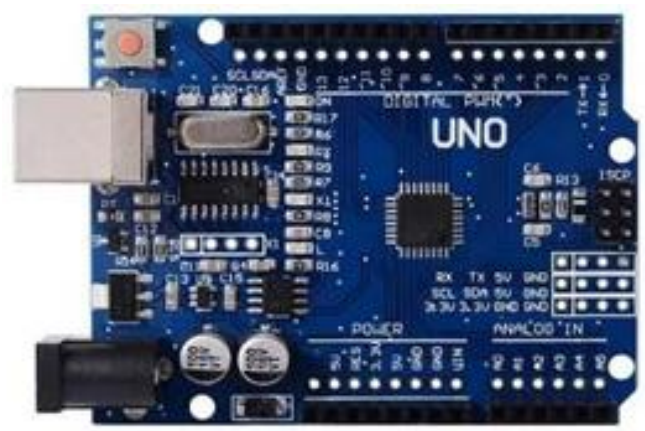

Gambar 2. Arduino Uno

Arduino Uno R3 adalah development board mikrokontroler yang berbasis chip ATmega328P.. Arduino Uno memiliki 14 digital pin input / output (atau biasa ditulis

I/O, dimana 6 pin diantaranya dapat digunakan sebagai output PWM), 6 pin input analog, menggunakan crystal $16 \mathrm{MHz}$, koneksi USB, jack listrik, header ICSP dan tombol reset. Hal tersebut adalah semua yang diperlukan untuk mendukung sebuah rangkaian mikrokontroler.. Chip ATmega328 pada Arduino Uno R3 memiliki memori 32 KB, dengan $0.5 \mathrm{~KB}$ dari memori tersebut telah digunakan untuk bootloader.

\section{B. Mekanik perangkat}


Setiap node baik itu node server atau node sensor menggunakan Arduino uno, nRF24101+, adapter, sensor gas MQ-7 dan senuah catu daya baterai seperti yang ditunjukkan pada gambar berikut

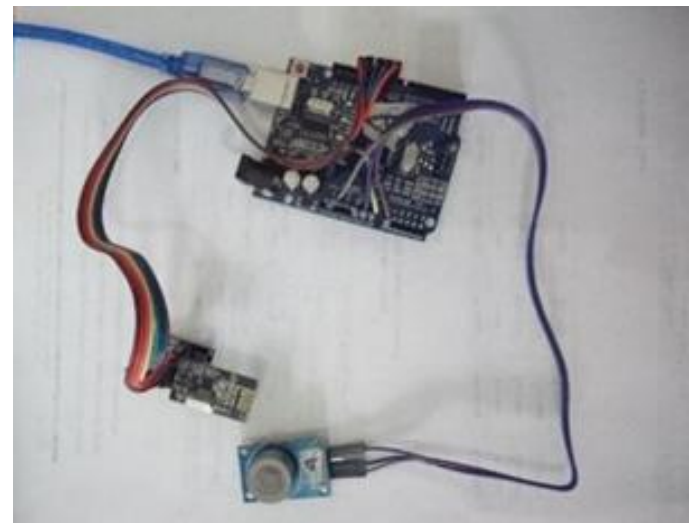

Gambar 3. Perangkat sensor node

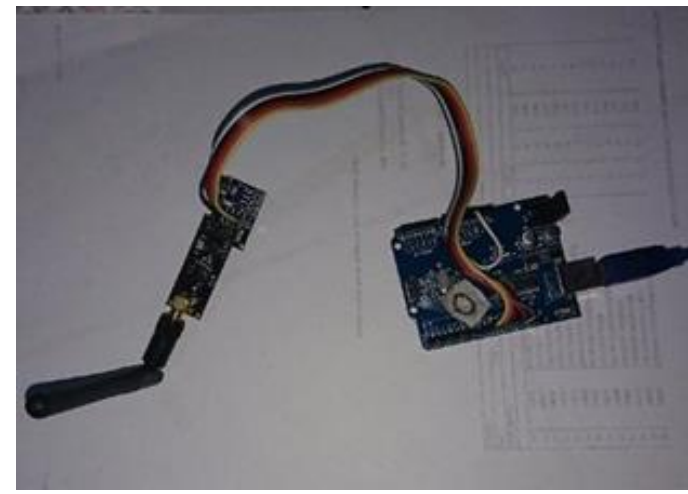

Gambar 4. Perangkat server node

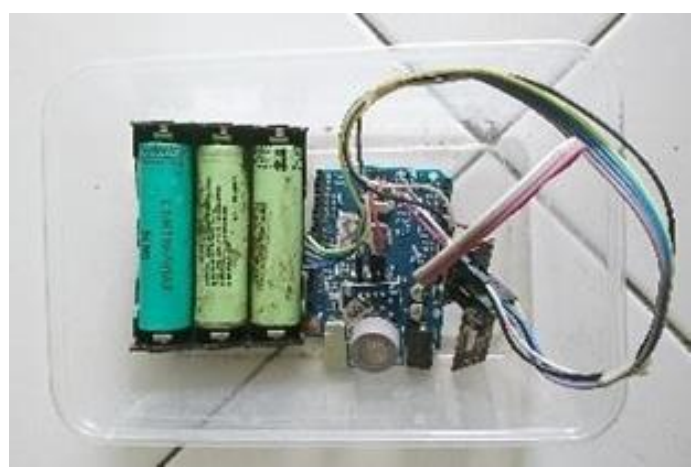

Gambar 5. Perangkat secara lengkap

Setiap node terdapat sebuah sensor mq-7 yang berfungsi intuk mengambil data gas co di udara bebas kemudian dikirim ke node node disekitarnya yang dituju untuk diteruskan ke node server

\section{Wiring diagram}

Pada penelitian ini menggunakan arduino uno yang didalamnya tertanam processor ATMEGA328. Perangkat nRF24L01+ yang dipasang pada adapter vcc 3.3V untuk menjaga kestabilan suplay energi listrik pada modul. Sensor Gas CO MQ-7 dengan daya 5 volt.

Pada perangkat bekerja, arduino membutuhkan 5 volt. Perangkat nRF24L01+ membutuhkan 3,3 volt dan sensor gas $\mathrm{CO}$ membutuhkan 5 volt. Konsumsi arus perangkat nRF24L01+ saat daya diatur MIN membutuhkan arus $7 \mathrm{~mA}$ 
Procedia of Engineering and Life Science Vol.1 No. 1 March 2021

Seminar Nasional \& Call for Paper Fakultas Sains dan Teknologi (SENASAINS 1st)

Universitas Muhammadiyah Sidoarjo

dan jika daya diatur MAX membutuhkan arus 12,5 mA. Untuk konsumsi arus sensor Gas CO membutuhkan arus 127 mA- $135 \mathrm{~mA}$ pada setiap sensornya.

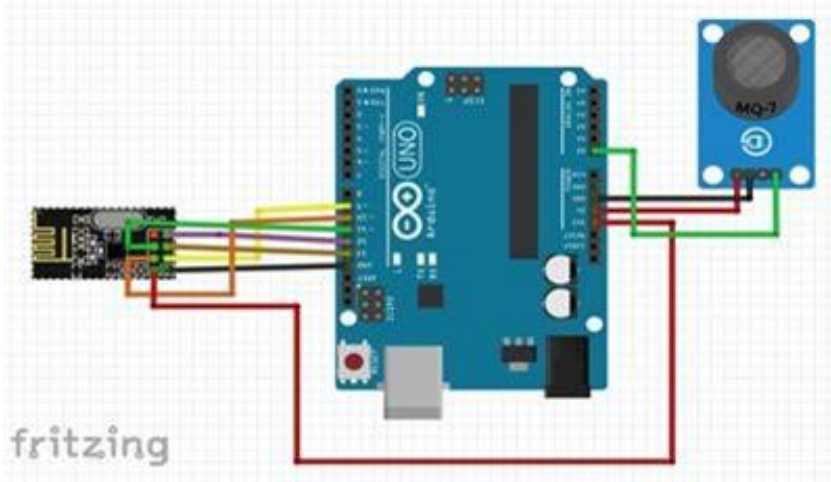

Gambar 6. Wiring Diagram Perangkat

Tabel 1. Pin Modul Wireless Ke Arduino

\begin{tabular}{lll}
\hline Kaki & nrf24101+ & arduino \\
\hline 1 & Ground & Ground \\
\hline 2 & Vcc & 5 volt \\
\hline 3 & CE & 9 \\
\hline 4 & CSN & 10 \\
\hline 5 & SCK & 13 \\
\hline 6 & MOSI & 11 \\
\hline 7 & MISO & 12 \\
\hline 8 & IRQ & NC \\
\hline
\end{tabular}

\section{Diagram blok sistem}

Berikut ini adalah gambaran umum diagram blok sistem dari perangkat yang akan dibangun

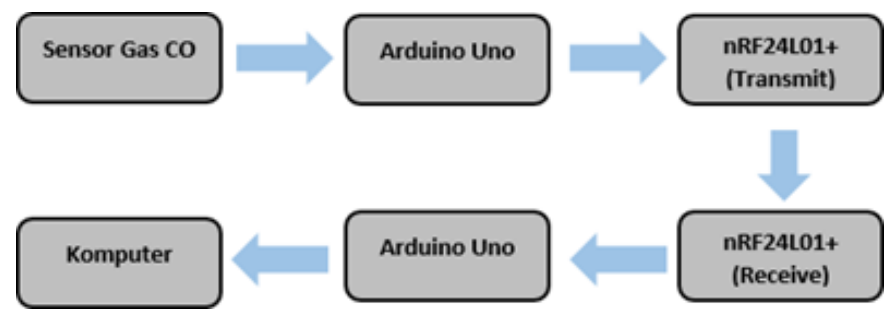

Gambar 7. Blok diagram system

Hasil output akhir dari data yang diterima dari masing-masing sensor yang berjumlah 9 buah sensor node akan ditampilkan pada layar serial komputer. 
Procedia of Engineering and Life Science Vol.1 No. 1 March 2021

Seminar Nasional \& Call for Paper Fakultas Sains dan Teknologi (SENASAINS $1^{\text {st }}$ )

Universitas Muhammadiyah Sidoarjo

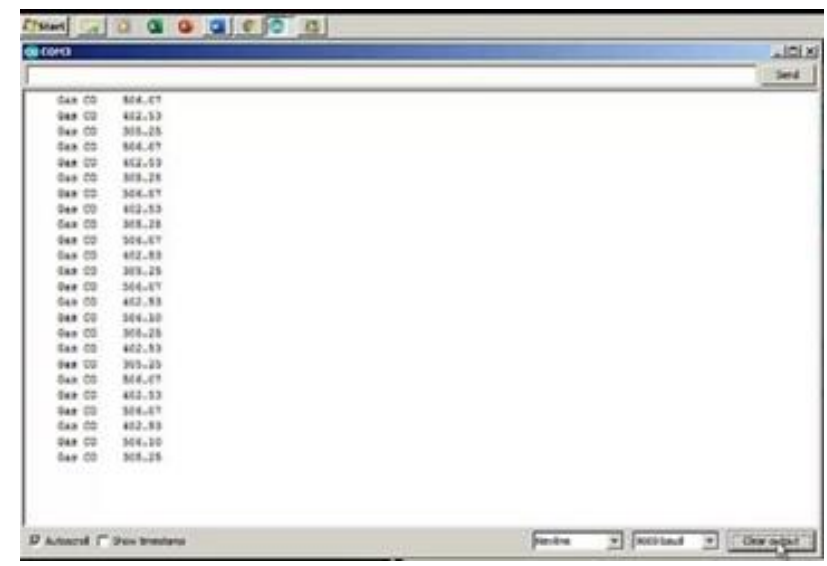

Gambar 8. Tampilan Serial Monitor Arduino

\section{E. Flowchart}

Berikut adalah flowchart dari sistem

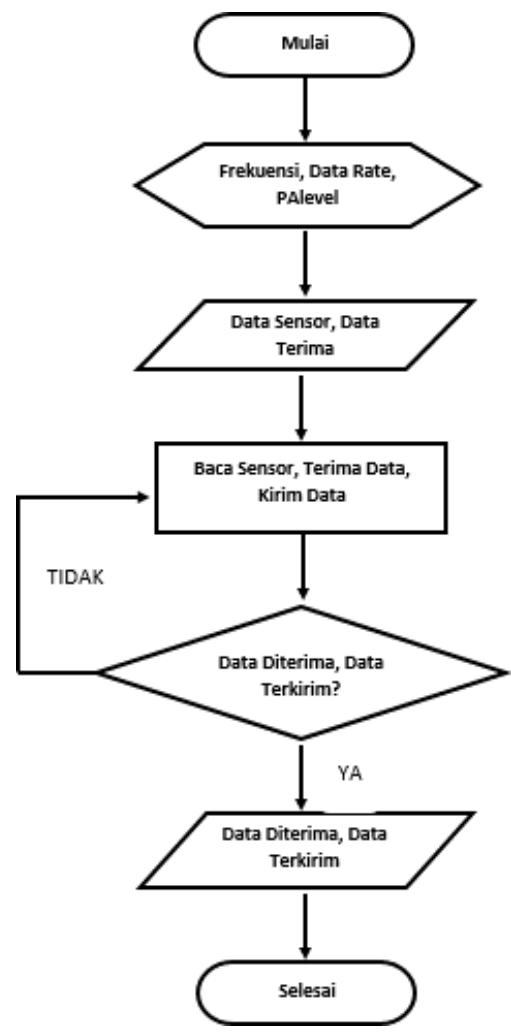

Gambar 9. Flowchart sistem

\section{F. Skema skenario pengujian}

Skenario pengujian berfungsi untuk mengetahui hasil pengiriman data pada perangkat wsn 9 node. Pengujian dengan topologi menggunakan star. Persebaran atau penempatan sensor node mengunakan persebaran statik dan persebarannya disesuaikan dengan jarak masing-masing antar node ke server adalah 5 meter, 10 meter, 15 meter, 20 meter dan terakhir 25 meter. Skema topologi star yang digunakan untuk kegiatan pengujian adalah sebagai berikut: 


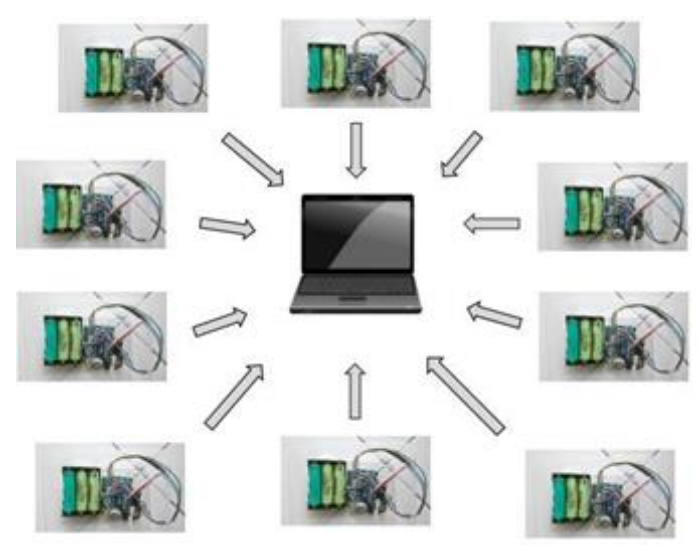

Gambar 10. Skema pengujian

\section{Hasil dan Pembahasan}

\section{A. Pengujian jarak terjauh}

Pengujian jarak terjauh dilakukan di area taman kampus Universitas Trunojoyo Madura. Jarak terjauh yang dapat dijangkau oleh perangkat nRF24101+ dengan halangan berupa pohon pohon di area kampus dengan tinggi 3-5 meter adalah mendapat hasil sebagai berikut

Tabel 2. Pengujian Jarak Jangkauan

\begin{tabular}{lc}
\hline Energi & Jarak terjauh \\
\hline Min & \pm 100 meter \\
\hline Max & \pm 130 meter \\
\hline
\end{tabular}

Pengujian jarak terjauh $(\max )$ tersebut dikatakan berhenti apabila node server tidak bisa menerima lagi data yang dikirim oleh pengirim

\section{B. Pengujian wireless sensor network}

Pengujian komunikasi pengiriman menggunakan modul radio nRF24L01pada malam hari dengan menggunakan topologi star seperti yng tampak pada gambar pengujian. Semua node di tetapkan energinya sebagai HIGH atau max dan juga penggunaan data rate sebesar $250 \mathrm{Kbps}$ pada jarak berwariasi dari 5 meter, 10 meter, 15 meter, 20 meter dan 25 meter dipilh jarak tersebut karena pada jarak 30 meter pengiriman paket data dengan keberhasilan sebesar 96,39\%. Berdasarkan penelitian sebelumnya, pengiriman data perangkat komunikasi radio nRF24L01+ ini tidak dipengaruhi oleh letak sudut pengirim dan penerima akan tetapi sangat dipengaruhi halangan seperi tembok, pohon ataupun bangunan. Dengan adanya halangan maka akan terjadi peredaman, interferensi, pembelokan gelombang radio yang dipancarkan oleh perangkat. Pada saat pengujian, node ditempatkan menyesuaikan seperti bentuk topologi yang telah ditetapkan dengan jarak masing masing yang telah ditentukan

Perhitungan paket loss dilakukan dalam bentuk presentase yang sesuai dengan rumus berikut

$$
\text { Paket loss }(\%)=\frac{\text { paket yang dikirim-paket yang diterima }}{\text { paket yang dikirim }} \times 100 \%
$$

Topologi atau penempatan sensor node disesuaikan dengan posisi seperti pada gambar di bawah ini. Dengan 9 buah node sensor dan sebuah node server yang terhubung ke laptop. Jarak yang digunakan adalah jarak 5 meter, 10 meter, 15 meter, 20 meter dan 25 meter dengan masing masing 3 kali percobaan.

Jarak 5 meter

Pada pengujian kali ini node no 2,3,6 dan 8 dan tidak berfungsi dengan baik ditandai dengan tidak ada data yang terkirim sama sekali kepada node server meskipun telah direset ulang. Pengujian ini dilakukan sebanyak 3 kali pengujian, dengan masing-masing pengujian dikirim data sebanyak 60 kali atau waktu 60 detik dengan delay masingmasing 1 detik. 
Procedia of Engineering and Life Science Vol.1 No. 1 March 2021

Seminar Nasional \& Call for Paper Fakultas Sains dan Teknologi (SENASAINS $1^{\text {st }}$ )

Universitas Muhammadiyah Sidoarjo

Tabel 3. Tabel Pengujian Pada Jarak 5 Meter

\begin{tabular}{|c|c|c|c|c|c|c|c|c|c|c|}
\hline \multirow[b]{2}{*}{ No } & \multirow[b]{2}{*}{ Node } & \multirow[b]{2}{*}{ Kirim } & \multicolumn{3}{|c|}{ Terima } & \multicolumn{3}{|c|}{ Paket $\operatorname{loss}(\%)$} & \multirow{2}{*}{$\begin{array}{c}\text { Rrata2 } \\
\text { paket } \\
\operatorname{loss}(\%)\end{array}$} & \multirow{2}{*}{$\operatorname{Berhasil}(\%)$} \\
\hline & & & $\begin{array}{c}\text { Percobaan } \\
1\end{array}$ & $\begin{array}{c}\text { Percobaan } \\
2\end{array}$ & $\begin{array}{c}\text { Percobaan } \\
3\end{array}$ & 1 & 2 & 3 & & \\
\hline 1 & 1 & 60 & 40 & 39 & 41 & 33,33 & 35 & 31,67 & 33,33 & 66,67 \\
\hline 2 & 2 & 60 & & & & & & & & \\
\hline 3 & 3 & 60 & & & & & & & & \\
\hline 4 & 4 & 60 & 52 & 52 & 50 & 13,33 & 13,33 & 16,67 & 14,44 & 86,67 \\
\hline 5 & 5 & 60 & 42 & 40 & 40 & 30 & 33,33 & 33,33 & 32,22 & 70 \\
\hline 6 & 6 & 60 & & & & & & & & \\
\hline 7 & 7 & 60 & 52 & 51 & 52 & 13,33 & 15 & 13,33 & 13,89 & 86,67 \\
\hline 8 & 8 & 60 & & & & & & & & \\
\hline 9 & 9 & 60 & 60 & 59 & 60 & 0 & 1,67 & 0 & 0,56 & 100 \\
\hline jun & $\begin{array}{l}\text { ah sen } \\
\text { terkir }\end{array}$ & $\begin{array}{l}\text { la data } \\
\text { n }\end{array}$ & 246 & 241 & 243 & & & & & \\
\hline \multicolumn{6}{|c|}{ Rata-rata paket loss node hidup } & 18 & 19,67 & 19 & & 82 \\
\hline
\end{tabular}

Dari tabel penguian diatas diketahui bahwa node yang hidup pada pengujian jarak 5 meter adalah node nomor 1,4,5,7 dan 9 dengan sebagian node yang lain mati, didapat hasil rata- rata paket loss total node yang hidup pada jarak 5 meter adalah $18 \%$ dan percobaan kedua dengan paket loss 19,67\% dan percobaan ketiga dengan paket loss $19 \%$.

Jarak 10 meter

Pada pengujian kali ini node no 3 dan 6 dan tidak berfungsi meskipun telah direset ulang. Pada pengujian ini dilakukan sebanyak 3 kali pengujian, dengan masing-masing pengujian dikirim data sebanyak 60 kali atau waktu 60 detik dengan delay 1 detik didapat hasil sebagai beriukut

Tabel 4. Tabel Pengujian Pada Jarak 10 Meter

\begin{tabular}{|c|c|c|c|c|c|c|c|c|c|c|}
\hline \multirow{2}{*}{ No } & \multirow{2}{*}{ Node } & \multirow{2}{*}{ kirim } & \multicolumn{3}{|c|}{ Terima } & \multicolumn{3}{|c|}{ Paket $\operatorname{loss}(\%)$} & \multirow{2}{*}{$\begin{array}{c}\text { Rata2 } \\
\text { paket } \\
\text { loss( } \% \\
)\end{array}$} & \multirow{2}{*}{$\begin{array}{c}\text { Berhasi } \\
\text { l } \\
(\%)\end{array}$} \\
\hline & & & $\begin{array}{c}\text { Percobaan } \\
1\end{array}$ & $\begin{array}{c}\text { Percobaa } \\
\text { n } 2\end{array}$ & $\begin{array}{c}\text { Percobaan } \\
3\end{array}$ & 1 & 2 & 3 & & \\
\hline 1 & 1 & 60 & 37 & 36 & 35 & 38,33 & 38,33 & 41,67 & 39,44 & 60,56 \\
\hline 2 & 2 & 60 & & 4 & 4 & 100 & 100 & 93,33 & 97,78 & 2,22 \\
\hline 3 & 3 & 60 & & & & & & & & \\
\hline 4 & 4 & 60 & 44 & 39 & 38 & 26,67 & 26,67 & 36,67 & 30 & 70 \\
\hline 5 & 5 & 60 & 36 & 37 & 37 & 40 & 40 & 38,33 & 39,44 & 60,56 \\
\hline 6 & 6 & 60 & & & & & & & & \\
\hline 7 & 7 & 60 & 45 & 44 & 42 & 25 & 25 & 30 & 26,67 & 73,33 \\
\hline 8 & 8 & 60 & & 5 & 4 & 100 & 100 & 93,33 & 97,78 & 2,22 \\
\hline 9 & 9 & 60 & 42 & 40 & 43 & 30 & 30 & 28,33 & 29,44 & 70,56 \\
\hline ju & $\begin{array}{l}\text { h sem } \\
\text { terkir }\end{array}$ & data & 204 & 205 & 203 & & & & & \\
\hline
\end{tabular}

rata paket loss node hidup

$32 \quad 32 \quad 35$

Dari tabel diketahui bahwa node yang hidup pada pengujian jarak 10 meter adalah node nomor 1,2,4,5,7,8 dan 9 dengan node 3 dan 6 yang lain tidak berfungsi. Didapat hasil rata-rata paket loss total node yang hidup jarak 10 meter adalah $32 \%$ dan pada percobaan kedua dengan paket loss $32 \%$ dan percobaan ketiga dengan paket loss $35 \%$. 
Procedia of Engineering and Life Science Vol.1 No. 1 March 2021

Seminar Nasional \& Call for Paper Fakultas Sains dan Teknologi (SENASAINS $1^{\text {st }}$ )

Universitas Muhammadiyah Sidoarjo

Jarak 15 meter

Pada pengujian kali ini node no 1,3,5,6,8 dan tidak berfungsi dengan baik meskipun telah direset ulang. Pada pengujian ini dilakukan sebanyak 3 kali pengujian, dengan masing-masing pengujian dikirim data sebanyak 60 kali atau waktu 60 detik dengan delay 1 detik. Pada pengujian ini didapat hasil sebagai berikut.

Tabel 5. Tabel Pengujian Pada Jarak 15 Meter

\begin{tabular}{|c|c|c|c|c|c|c|c|c|c|c|}
\hline \multirow[b]{2}{*}{ No } & \multirow[b]{2}{*}{ Node } & \multirow[b]{2}{*}{ Kirim } & \multicolumn{3}{|c|}{ Terima } & \multicolumn{3}{|c|}{ Paket $\operatorname{loss}(\%)$} & \multirow{2}{*}{$\begin{array}{c}\text { Rata2 } \\
\text { paket } \\
\text { loss }(\% \\
)\end{array}$} & \multirow{2}{*}{$\begin{array}{c}\text { Rata2 } \\
\text { Berhasi } \\
\mathbf{l} \\
(\%)\end{array}$} \\
\hline & & & $\begin{array}{c}\text { Percobaan } \\
1\end{array}$ & $\begin{array}{c}\text { Percobaan } \\
2\end{array}$ & $\begin{array}{c}\text { Percobaan } \\
3\end{array}$ & 1 & 2 & 3 & & \\
\hline 1 & 1 & 60 & & & & & & & & \\
\hline 2 & 2 & 60 & 2 & 3 & 4 & 96,67 & 95 & 93,33 & 95 & 5 \\
\hline 3 & 3 & 60 & & & & & & & & \\
\hline 4 & 4 & 60 & 25 & 24 & 23 & 58,33 & 60 & 61,67 & 60 & 40 \\
\hline 5 & 5 & 60 & & & & & & & & \\
\hline 6 & 6 & 60 & & & & & & & & \\
\hline 7 & 7 & 60 & 26 & 27 & 28 & 56,67 & 55 & 53,33 & 55 & 45 \\
\hline 8 & 8 & 60 & & & & & & & & \\
\hline 9 & 9 & 60 & 60 & 58 & 55 & 0 & 3,33 & 8,33 & 3,89 & 96,11 \\
\hline \multicolumn{3}{|c|}{$\begin{array}{c}\text { jumlah semua data } \\
\text { terkirim }\end{array}$} & 113 & 112 & 110 & & & & & \\
\hline \multicolumn{6}{|c|}{ rata paket loss node hidup $(\%)$} & 52,92 & 53,33 & 54,17 & & \\
\hline
\end{tabular}

Dari tabel penguian diatas diketahui bahwa node yang hidup pada pengujian jarak 15 meter adalah node nomor 2,4,7dan 9 dengan node 1,3,5,6 dan 8 yang tidak berfungsi. Masing-masing dilakukan 3 kali percobaan didapat hasil rata- rata paket loss total node hidup jarak 15 meter adalah 52,92\% dan percobaan kedua dengan paket loss 53,33\% dan percobaan ketiga dengan paket loss $54,17 \%$.

Jarak 20 meter

Pada pengujian kali ini node no 1,2,3,5,6,8 dan tidak berfungsi meskipun telah direset ulang. Pada pengujian ini dilakukan sebanyak 3 kali pengujian, dengan masing-masing pengujian dikirim data sebanyak 60 kali atau waktu 60 detik dengan delay 1 detik. Pada pengujian ini didapat hasil sebagai berikut

Tabel 6. Tabel Pengujian Pada Jarak 20 Meter

\begin{tabular}{|c|c|c|c|c|c|c|c|c|c|c|}
\hline \multirow[b]{2}{*}{ No } & \multirow[b]{2}{*}{ Node } & \multirow[b]{2}{*}{ Kirim } & \multicolumn{3}{|c|}{ Terima } & \multicolumn{3}{|c|}{ Paket $\operatorname{loss}(\%)$} & \multirow{2}{*}{$\begin{array}{c}\text { Rata2 } \\
\text { paket } \\
\text { loss } \\
(\%)\end{array}$} & \multirow{2}{*}{$\begin{array}{c}\text { Berhasi } \\
\mathbf{l} \\
(\%)\end{array}$} \\
\hline & & & $\begin{array}{c}\text { Percobaan } \\
1\end{array}$ & $\begin{array}{c}\text { Percobaan } \\
2\end{array}$ & $\begin{array}{c}\text { Percobaan } \\
3\end{array}$ & 1 & 2 & 3 & & \\
\hline 1 & 1 & 60 & & & & & & & & \\
\hline 2 & 2 & 60 & & & & & & & & \\
\hline 3 & 3 & 60 & & & & & & & & \\
\hline 4 & 4 & 60 & 18 & 21 & 21 & 70 & 65 & 65 & 66,67 & 33,33 \\
\hline 5 & 5 & 60 & & & & 100 & 100 & 100 & 100 & 0 \\
\hline 6 & 6 & 60 & & & & 100 & 100 & 100 & 100 & 0 \\
\hline 7 & 7 & 60 & 21 & 24 & 25 & 65 & 60 & $\begin{array}{c}58,3 \\
3\end{array}$ & 61,11 & 38,89 \\
\hline 8 & 8 & 60 & & & & 100 & 100 & 100 & 100 & 0 \\
\hline
\end{tabular}


Procedia of Engineering and Life Science Vol.1 No. 1 March 2021

Seminar Nasional \& Call for Paper Fakultas Sains dan Teknologi (SENASAINS $1^{\text {st }}$ )

Universitas Muhammadiyah Sidoarjo

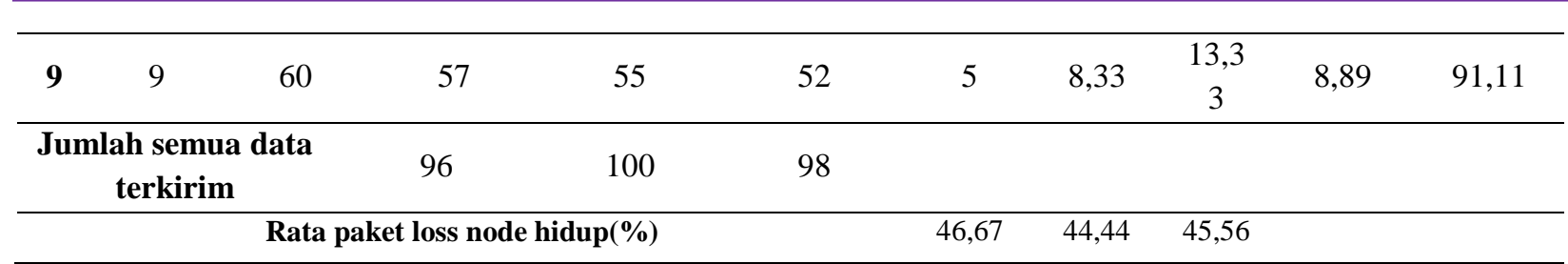

Dari tabel diatas diketahui bahwa node yang hidup pada pengujian jarak 20 meter adalah node nomor 4,7dan 9 dengan node 1,2,3,5,6 dan 8 yang tidak berfungsi. Masing-masing dilakukan 3 kali percobaan pertama didapat hasil rata-rata paket loss total adalah $46,67 \%$ dan pada percobaan kedua dengan paket loss $44,44 \%$ dan percobaan ketiga dengan paket loss $45,56 \%$.

\section{Jarak 25 meter}

Pada pengujian kali ini node no 1,2,3,5,6,8 dan tidak berfungsi dengan baik meskipun telah direset ulang. Pada pengujian ini dilakukan sebanyak 3 kali pengujian, dengan masing-masing pengujian dikirim data sebanyak 60 kali atau waktu 60 detik dengan delay 1 detik. Pada pengujian ini didapat hasil sebagai berikut

Tabel 7. Tabel Pengujian Pada Jarak 25 Meter

\begin{tabular}{|c|c|c|c|c|c|c|c|c|c|c|}
\hline \multirow[t]{2}{*}{ No } & \multirow[t]{2}{*}{ Node } & \multirow[t]{2}{*}{ Kirim } & \multicolumn{3}{|c|}{ Terima } & \multicolumn{3}{|c|}{ paket $\operatorname{loss}(\%)$} & \multirow{2}{*}{$\begin{array}{c}\text { rata2 } \\
\text { paket } \\
\text { loss } \\
(\%)\end{array}$} & \multirow{2}{*}{$\begin{array}{c}\text { Berhasil } \\
(\%)\end{array}$} \\
\hline & & & $\begin{array}{c}\text { Percobaan } \\
1\end{array}$ & $\begin{array}{c}\text { Percobaan } \\
2\end{array}$ & $\begin{array}{c}\text { Percobaan } \\
3\end{array}$ & 1 & 2 & 3 & & \\
\hline 1 & 1 & 60 & & & & & & & & \\
\hline 2 & 2 & 60 & & & & & & & & \\
\hline 3 & 3 & 60 & & & & & & & & \\
\hline 4 & 4 & 60 & & & & & & & & \\
\hline 5 & 5 & 60 & & & & & & & & \\
\hline 6 & 6 & 60 & & & & & & & & \\
\hline 7 & 7 & 60 & & & & & & & & \\
\hline 8 & 8 & 60 & & & & & & & & \\
\hline 9 & 9 & 60 & 26 & 28 & 28 & 56,67 & 53,33 & $\begin{array}{c}53,3 \\
3\end{array}$ & 54,44 & 45,56 \\
\hline \multicolumn{3}{|c|}{$\begin{array}{c}\text { jumlah semua data } \\
\text { terkirim }\end{array}$} & 26 & 28 & 28 & & & & & \\
\hline & & rata & aket loss no & hidup & & 56,67 & 53,33 & 53,33 & & \\
\hline
\end{tabular}

Dari tabel penguian diatas diketahui bahwa node yang hidup pada pengujian jarak 25 meter adalah node nomor 9 Masing-masing dilakukan 3 kali percobaan didapat hasil paket loss total pada percobaan pertama adalah 55,67\% dan pada percobaan kedua dengan paket loss 53,33\% dan percobaan ketiga dengan paket loss 53,33\%.

\section{KESIMPULAN}

Dari beberapa kegiatan dapat disimpulkan bahwa odul nRF24L01+ memiliki jarak jangkau maksimal saat energi diatur MIN mencapai 100 meter sedangkan saat energi diatur MAX mencapai 130 meter dengan halangan pepohonan. Sensorgas CO semuanya dapat membaca gas co dengan stabil. Semakin jauh jarak pengiriman maka presentase paket loss semakin tinggi. Semakin banyak node yg bekerja pada suatu topologi akan meningkatkan tabrakan data dan interferensigelombang sehingga paket yang terkirim tidak sempurna atau tidak dapat terkirim sehingga menyebabkan paket loss yang besar.

Dalam hal ini penulis memberi saran terkait dengan perancangan alat adalah Pada penelitian selanjutnya sebaiknya menggunakan baterai yang memiliki kapasitas daya yang lebihbesar sehingga lebih awet dalam jangka waktu yang lebih lama.Memberikan wadah yang kuat dan aman untuk melindungi perangkat dari goncangan Diperlukan hasil penelitian yang lebih mendalam apabila sistem wireless sensor network denganbanyak node menggunakan perangkat nRF24L01 ini jika diaplikasikan untuk skala yang besar, mengingat hasil penelitian ini didapatkan hasil yang kurang baik dalam pengiriman data dan keberhasilan data terkirim menggunakan perangkat ini. 


\section{REFERENSI}

[1] M.Dzulkifli S, Muhammad Rivai, Suwito. 2016. "Rancang Bangun Sistem Irigasi Tanaman Otomatis Menggunakan Wireless Sensor Network” Surabaya: JURNAL TEKNIK ITS Vol. 5, No. 2, (2016) ISSN: 2337 3539 (2301-9271 Print) A261-A266

[2] Burhan Fajriansyah, Muhammad Ichwan, Ratna Susana. 2016. "Evaluasi Karakteristik XBee Pro dan nRF24L01+ sebagai Transceiver Nirkabel" Bandung: Jurnal ELKOMIKA | Vol. 4 | No. 1 | Halaman 83 - 97 ISSN (p): 2338-8323 Januari - Juni 2016 ISSN (e): 2459-9638

[3] Ahmad Sabiq, Nurmaya, Topan Alfarisi. 2017. "Sistem Wireless Sensor Network Berbasis Arduino Uno dan Raspberry Pi untuk Pemantauan Kualitas Udara di Cempaka Putih Timur, Jakarta Pusat" Yogyakarta: CITEE 2017 Yogyakarta, 27 Juli 2017 ISSN: 2085-6350 301-305

[4] Upik Jamil Shobrina, Rakhmadhany Primananda, Rizal Maulana. 2018. "Analisis Kinerja Pengiriman Data Modul Transceiver NRF24L01, Xbee dan Wifi ESP8266 Pada Wireless Sensor Network" Malang: Jurnal Pengembangan Teknologi Informasi dan Ilmu Komputer e-ISSN: 2548-964X Vol. 2, No. 4, April 2018, hlm. 1510- 1517 http://j-ptiik.ub.ac.id

[5] Lilik Hasanah, Heru Yuwono, Ahmad Aminudin. 2018. " Multi-Hop Wireless Sensor Network Performance and Energy Simulation" Bandung: Pertanika J. Sci. \& Technol. 26 (1): 427 - 440

[6] Suroto, Ahmad, 2018, Air Condition Monitoring Using Waypoint Based Uav (Unmanned Aerial Vehicle), International Journal of Science, Engineering And Information Technology, Department of Electronics, University of Trunojoyo Madura 